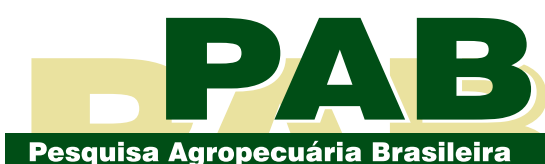

ISSN 1678-3921

Journal homepage: www.embrapa.br/pab

For manuscript submission and journal contents, access: www.scielo.br/pab

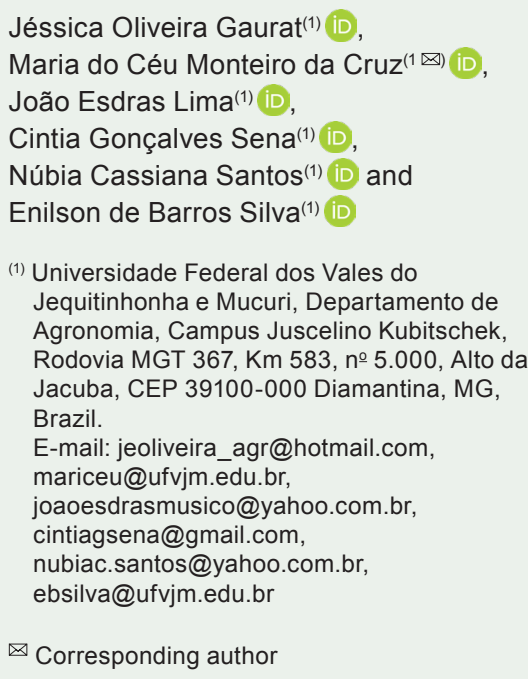

Jéssica Oliveira Gaurat ${ }^{(1)}$ (D),

Maria do Céu Monteiro da Cruz ${ }^{(1 凶)}($ iD , João Esdras Lima ${ }^{(1)}(\mathrm{D}$,

Cintia Gonçalves Sena ${ }^{(1)}$ (iD),

Núbia Cassiana Santos ${ }^{(1)}$ (iD and

Enilson de Barros Silva(1) (iD)

(1) Universidade Federal dos Vales do Jequitinhonha e Mucuri, Departamento de Agronomia, Campus Juscelino Kubitschek, Rodovia MGT 367, Km 583, o⒌000, Alto da Jacuba, CEP 39100-000 Diamantina, MG, Brazil.

E-mail: jeoliveira_agr@hotmail.com, mariceu@ufvjm.edu.br, joaoesdrasmusico@yahoo.com.br cintiagsena@gmail.com, nubiac.santos@yahoo.com.br. ebsilva@ufvjm.edu.br

$\bowtie$ Corresponding author

Received

August 13, 2020

Accepted

September 29, 2020

How to cite

GAURAT, J.O.; CRUZ, M. do C.M. da; LIMA

J.E.; SENA, C.G.; SANTOS, N.C.; SILVA, E. de

B. Foliar nutrient content and yield performance of blackberry with potassium fertilization.

Pesquisa Agropecuária Brasileira, v. 55 e02198, 2020. DOI: https://doi.org/10.1590/ S1678-3921.pab2020.v55.02198

\section{Foliar nutrient contents and yield performance of blackberry with potassium fertilization}

\begin{abstract}
The objective of this work was to evaluate the yield performance and foliar nutrient contents of blackberry (Rubus sp.) cultivars in response to the increase in potassium fertilization. The experiment was carried out in a soil with pH 5.2 and $22 \mathrm{mg} \mathrm{dm}^{-3} \mathrm{~K}$ content in the fourth and fifth years of production of the Brazos, Guarani, BRS Tupy, and BRS Xavante cultivars, grown in the state of Minas Gerais, Brazil. The tested $\mathrm{K}_{2} \mathrm{O}$ rates were distributed in a $4 \times 4$ factorial arrangement, which consisted of four rates of $\mathrm{K}_{2} \mathrm{O}$ per plant $(10,20,30$, and $40 \mathrm{~g})$ and of the four blackberry cultivars, distributed in four randomized complete block designs. The maximum economic efficiency (MEE) yield, the formation of primocanes, and the critical level of foliar nutrients were evaluated. The $\mathrm{K}$ fertilization recommended for blackberry cultivation in Brazilian conditions is not sufficient to maintain foliar nutrient contents at an adequate level. Fertilization with $20 \mathrm{~g}$ per plant per year of $\mathrm{K}_{2} \mathrm{O}$, twice the recommended amount, favors the MEE yield, compatible with the yield performance of the cultivars. Foliar nutrient contents should be evaluated to recommend the proper fertilization for the orchard to reach its maximum yield potential.
\end{abstract}

Index terms: Rubus, mineral nutrition, yield.

\section{Teores de nutrientes foliares e desempenho produtivo de amoreira-preta com fertilização potássica}

Resumo - O objetivo deste trabalho foi avaliar o desempenho produtivo e os teores de nutrientes foliares em cultivares de amoreira-preta (Rubus sp.), em resposta ao aumento na adubação potássica. $\mathrm{O}$ experimento foi realizado em solo com pH 5,2 e $22 \mathrm{mg} \mathrm{dm}^{-3}$ de K, no quarto e no quinto ano de produção das cultivares Brazos, Guarani, BRS Tupy e BRS Xavante, cultivadas no estado de Minas Gerais, Brasil. As doses de $\mathrm{K}_{2} \mathrm{O}$ testadas foram distribuídas em arranjo fatorial $4 \mathrm{x} 4$, que consistiu em quatro doses de $\mathrm{K}_{2} \mathrm{O}$ por planta $(10,20,30 \mathrm{e} 40 \mathrm{~g}$ ) e nas quatro cultivares de amoreira-preta, distribuídas em quatro delineamentos de blocos ao acaso. Foram avaliados a produtividade considerada de máxima eficiência econômica (MEE), a formação de hastes novas e o nível crítico de nutrientes foliares. A fertilização com $\mathrm{K}$ recomendada para o cultivo da amoreira-preta, nas condições brasileiras, não é suficiente para manter os teores de nutrientes nas folhas em nível adequado. A adubação com $20 \mathrm{~g}$ por planta por ano de $\mathrm{K}_{2} \mathrm{O}$, o dobro da recomendada, favorece produtividade de MEE compatível com o desempenho produtivo das cultivares. Os teores de nutrientes foliares devem ser avaliados para recomendação da fertilização adequada para o pomar alcançar seu potencial máximo de rendimento.

Termos para indexação: Rubus, nutrição mineral, produtividade. 


\section{Introduction}

The use of fertilization rates recommended in other countries in Brazilian conditions creates problems for the blackberry (Rubus sp.) production system, such as a slow or excessive plant development, susceptibility to pests and diseases, and a low yield and fruit quality (Pereira et al., 2015a). Therefore, information on blackberry fertilization needs to be improved based on the response of different cultivars in Brazilian regions, considering foliar nutrient contents and plant yield.

Fertilization, however, is currently recommended based only on soil analysis. Depending on the nutrient content of the soil, the recommended potassium rates for orchard maintenance range from 0 to $66.7 \mathrm{~kg} \mathrm{ha}^{-1}$ $\mathrm{K}_{2} \mathrm{O}$ (Manual..., 2016). In countries that consider soil and primocane $\mathrm{K}$ contents, the applied amount may be as high as $112 \mathrm{~kg} \mathrm{ha}^{-1} \mathrm{~K}_{2} \mathrm{O}$ (Hart et al., 2006).

In plants, potassium performs an important function in regulating the osmotic potential of cells, acting as an activator of many enzymes involved in respiration and photosynthesis (Castaño et al., 2008). Therefore, high quantities of the nutrient have been applied to blackberry in high-yield situations, especially since K can also induce growth, increase yield, and influence fruit firmness when nitrogen is not limiting (Pereira et al., 2015b).

Research conducted with blackberry cultivars in Brazil has shown that the current $\mathrm{K}$ fertilizer recommendation is low. Pereira et al. (2015b), for example, observed that $\mathrm{K}$ foliar content stays below normal for optimal plant growth and yield, which is an indicative that $\mathrm{K}$ fertilization may be limiting the yield potential of the cultivars.

The objective of this work was to evaluate the the yield performance and foliar nutrient content of blackberry cultivars in response to the increase in potassium fertilization.

\section{Materials and Methods}

The experiment was carried out in an orchard, located in the municipality of Diamantina, in the state of Minas Gerais, Brazil (18 $14^{\prime} 56^{\prime \prime} \mathrm{S}, 43^{\circ} 36^{\prime} 0^{\prime \prime} \mathrm{W}$, at an altitude of $1,387 \mathrm{~m}$ ), during the fourth and fifth years of production after planting of blackberry cultivars. The climate of the region is Cwb, temperate humid, according to Köppen-Geiger, characterized by a well-defined dry and rainy season. Accumulated precipitation, temperature variations, and the number of cold hours at mild temperatures were recorded in the two evaluated cycles, between January 2016 and January 2018, at an automatic weather station, approximately $300 \mathrm{~m}$ from the orchard (Figure 1).

The soil in the experimental area is a Neossolo Quartzarênico (Santos et al., 2013), i.e., an Arenosol (IUSS Working Group WRB, 2015), with $830 \mathrm{~g} \mathrm{~kg}^{-1}$ sand, $100 \mathrm{~g} \mathrm{~kg}^{-1}$ clay, and $70 \mathrm{~g} \mathrm{~kg}^{-1}$ silt. At $0-20-\mathrm{cm}$ depth, the organic matter content was $1.2 \mathrm{dag} \mathrm{kg}^{-1}$. The soil analysis, prior to the start of experiment, showed the following characteristics: $\mathrm{pH} 5.1 ; 7.5$ and $22.1 \mathrm{mg} \mathrm{dm}^{-3}$ $\mathrm{P}$ and $\mathrm{K}$, respectively, both extracted by Mehlich-1; 1.0 $\mathrm{cmol}_{\mathrm{c}} \mathrm{dm}^{-3} \mathrm{Ca} ; 0.4 \mathrm{cmol}_{\mathrm{c}} \mathrm{dm}^{-3} \mathrm{Mg}$ extracted by $\mathrm{KCl} 1$ mol L ${ }^{-1}$; base saturation of $45.5 \%$; and cation exchange
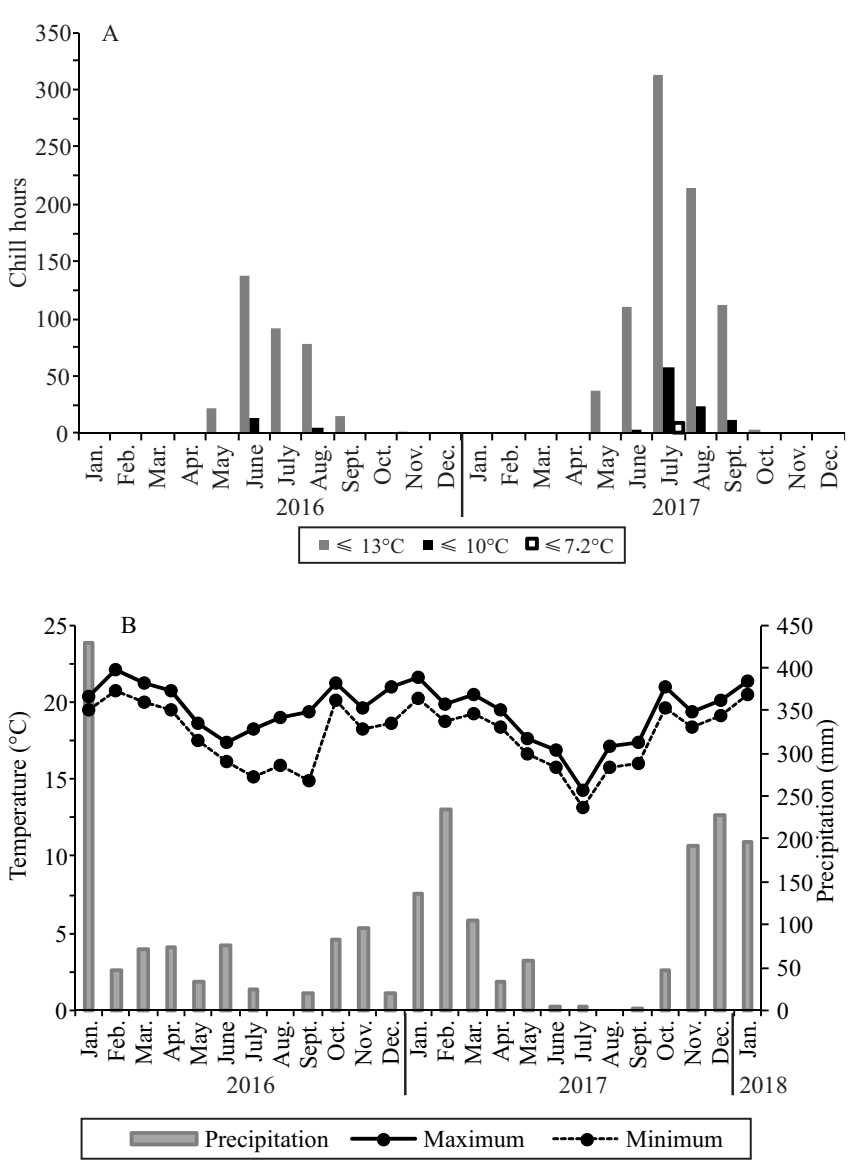

Figure 1. Chill-hours accumulated at temperatures below 13,10 , and $7.2^{\circ} \mathrm{C}(\mathrm{A})$ and monthly averages of the maximum and minimum temperatures (Ts) and of the precipitation (B) recorded in the blackberry (Rubus sp.) growing region, in the municipality of Diamantina, in the state of Minas Gerais, Brazil. 
capacity at $\mathrm{pH} 7.0$ of $5.5 \mathrm{cmol}_{\mathrm{c}} \mathrm{dm}^{-3}$ obtained by the Walkley-Black method.

The Brazos, Guarani, BRS Tupy, and BRS Xavante blackberry cultivars were evaluated at four and five years of age. These cultivars require a low chill of 200-300 hours $\left(<7.2^{\circ} \mathrm{C}\right)$. The plants were conducted in a double espalier, with two wires parallel at $0.5 \mathrm{~m}$, distanced $0.8 \mathrm{~m}$ from the soil, with a spacing of $0.8 \mathrm{~m}$ between plants and $2.5 \mathrm{~m}$ between rows, corresponding to a density of 5,000 plants per hectare.

The preparation of the area and the application of liming before planting and fertilization up to the third production cycle were carried out according to Antunes \& Raseira (2004) and to the chemical characteristics of the soil. Pruning was performed in summer, after harvest, by eliminating all the dry floricanes at soil level and reducing the primocanes to $1.2 \mathrm{~m}$ height. In winter, the canes and lateral shoots were reduced. Complementary irrigation was applied during fertilization, twice a week, if necessary.

Fertilization was split into two applications: one in March, during the growth of the primocanes; and the other in September, during the flowering period of the plants. The tested $\mathrm{K}_{2} \mathrm{O}$ rates were distributed in a $4 \mathrm{x} 4$ factorial arrangement, which consisted of four rates of $\mathrm{K}_{2} \mathrm{O}$ per plant (10, 20,30, and $40 \mathrm{~g}$ ) and of the four blackberry cultivars, distributed in four randomized complete block designs, with six plants per plot, leaving four plants as borders. Complementary fertilization was done with $30 \mathrm{~g} \mathrm{~N}$ and $50 \mathrm{~g} \mathrm{P}_{2} \mathrm{O}_{5}$ per plant; the used sources were urea, potassium chloride with $60 \% \mathrm{~K}_{2} \mathrm{O}$, and monoammonium phosphate containing $50 \% \mathrm{P}_{2} \mathrm{O}_{5}$ and $10 \% \mathrm{~N}$, which was considered in the calculation of the tested $\mathrm{N}$ rates.

Fruit yield was obtained from the mass of fruits harvested per plant, multiplied by planting density. Fruit were harvested two or three times per week, from October to February, in the fourth and fifth production cycles.

Cane density was determined for all plants at the end of the harvest period, considering the number of primocanes and the spacing between plants. The number of primocanes was obtained by counting the total number per plant, in each plot.

Foliar nutrient contents were determined from samples of the sixth fully-expanded leaf from the apex of the floricanes. Samples of leaf dry matter were subjected to nitric-perchloric digestion to determine:
P by colorimetry; K by flame photometry; calcium, magnesium, zinc, iron, copper, and manganese by atomic absorption spectrophotometry; and boron by incineration in a muffle furnace (Silva, 2009). Total $\mathrm{N}$ was obtained by the Kjeldahl method after sulfuric digestion (Malavolta et al., 1997).

Data were analyzed by the analysis of variance. Variables that differed significantly between the tested rates of $\mathrm{K}$ were subjected to regression analysis, and variables that differed significantly between cultivars were compared by Tukey's test, at 5\% probability. From the equations for maximum technical efficiency (MTE) yield, the recommended $\mathrm{K}$ rates necessary for the cultivars to obtain a maximum yield of $90 \%$ were estimated and considered as being of maximum economic efficiency (MEE). The critical levels of foliar nutrients were estimated by substituting the $\mathrm{K}$ rate associated with the MEE yield in the equations.

\section{Results and Discussion}

The $\mathrm{K}$ rates applied to the soil increased blackberry yield in the two evaluated cycles (Table 1). The average rates of 30 and $20 \mathrm{~g} \mathrm{~K}_{2} \mathrm{O}$ obtained for the MTE and MEE yields, respectively, are higher than that recommended for soils with a low K content of $10 \mathrm{~g}$ per plant (Manual..., 2016). With the rate for MEE, yield increased from 69 to $78 \%$, varying according to the cultivar, in comparison with plants fertilized with $10 \mathrm{~g} \mathrm{~K}_{2} \mathrm{O}$.

The observed increase in yield is attributed to the increase in the availability of $\mathrm{K}$ for the plants. Used in high quantities, this nutrient activates the enzymes involved in plant respiration and photosynthesis, regulates stomatal opening and cell turgor, increases $\mathrm{CO}_{2}$ fixation, promotes the transport of photoassimilates (Castaño et al., 2008), and favors the absorption of $\mathrm{NO}_{3}$ and protein formation (IPI, 2013).

However, there was decrease in the yield performance of the blackberry cultivars that received the recommended fertilization of $10 \mathrm{~g} \mathrm{~K}_{2} \mathrm{O}$ for soil with a low $\mathrm{K}$ content. At the lowest availability of $\mathrm{K}$ in the soil, the content of this nutrient in the leaves was below normal for a satisfactory plant growth and yield (Pereira et al., 2015b); this insufficient fertilization can cause impacts on the current and next crop cycles.

Therefore, it is necessary to adjust the currently recommended fertilization rates - that do not provide 
satisfactory yields in Brazilian conditions -, in order to meet the nutritional requirements of blackberry cultivars grown in soils with a low $\mathrm{K}$ content (Manual..., 2016). The need to adjust $\mathrm{K}$ fertilization to blackberry cultivars has already been verified for BRS Tupy and BRS Xavante, which have shown an increase in production with a $\mathrm{K}$ rate greater than the recommended (Pereira et al., 2015b). The problems caused by the existing fertilization recommendations may be primarily due to the fact they were developed in other countries (Pereira et al., 2013a, 2013b; Antunes et al., 2014).

Brazos was the most productive cultivar in the two evaluated cycles, regardless of the applied $\mathrm{K}$ rate, as previously reported (Antunes et al., 2014; Oliveira et al., 2017). The difference in yield between cultivars is related to their genetic characteristics and ability to adapt to different growing regions. In the present study, the chill hours were insufficient to meet the required $200-300$ hours $\left(<7.2^{\circ} \mathrm{C}\right)$ (Figure 1), showing how maximum yield is mainly related to climate and soil conditions and to plant nutrition, which influence plant growth, sprouting, and nutrient export (Pereira et al., 2013b, 2015a; Strik \& Bryla, 2014).
The increase in $\mathrm{K}$ rates increased the foliar $\mathrm{K}$ content of the evaluated cultivars in both study years (Table 2). Plants fertilized with a $\mathrm{K}$ rate of $10 \mathrm{~g} \mathrm{~K}_{2} \mathrm{O}$ showed a foliar $\mathrm{K}$ content lower than the range of 12.5 to $30 \mathrm{~g} \mathrm{~kg}^{-1}$, considered sufficient for the optimal growth of blackberry (Freire, 2007; Manual..., 2016). However, with a rate of $20 \mathrm{~g} \mathrm{~K}_{2} \mathrm{O}$, sufficient to achieve MEE yield, a foliar K content from 12.0 to $12.1 \mathrm{~g} \mathrm{~kg}^{-1}$ was observed.

The low foliar K content found may be related to the availability of the nutrient in the soil (Table 2). With fertilization at the recommended rate of $10 \mathrm{~g} \mathrm{~K}_{2} \mathrm{O}$, the soil presented 45.2 to $53.9 \mathrm{mg} \mathrm{dm}^{-3}$ of the nutrient, indicating an average availability; however, with an increased fertilization of $20 \mathrm{~g} \mathrm{~kg}^{-1} \mathrm{~K}_{2} \mathrm{O}$, the availability in the soil was classified as good, ranging from 75.1 to $82.7 \mathrm{mg} \mathrm{dm}^{-3}$.

The BRS Tupy and BRS Xavante cultivars also showed low foliar K contents when fertilized with the recommended rates for soils with average $\mathrm{K}$ contents. This is another indicative that the current $\mathrm{K}$ rates recommended for fertilization in Brazil are low and need to be updated, that is, increased (Pereira et al., 2015b).

Table 1. Fruit yield of the Brazos, Guarani, BRS Tupy, and BRS Xavante blackberry (Rubus sp.) cultivars in response to potassium fertilization, in the fourth and fifth production cycles ${ }^{(1)}$.

\begin{tabular}{|c|c|c|c|c|c|c|}
\hline \multirow[t]{2}{*}{ Cultivar } & \multirow[t]{2}{*}{ Equation $^{(2)}$} & \multirow[t]{2}{*}{$\mathrm{R}^{2}$} & \multicolumn{2}{|c|}{ Fruit yield $\left(\mathrm{Mg} \mathrm{ha}^{-1}\right)$} & \multicolumn{2}{|c|}{$\mathrm{K}_{2} \mathrm{O}$ rate (g per plant) } \\
\hline & & & MTE & MEE & MTE & MEE \\
\hline & \multicolumn{6}{|c|}{ Fourth production cycle } \\
\hline Brazos & $\hat{y}=3.45+0.554 x-0.0082 x^{2 * *}$ & 94.4 & $12.8 \mathrm{a}$ & $11.5 \mathrm{a}$ & 34.4 & 21.0 \\
\hline Guarani & $\hat{y}=2.4+0.403 x-0.0075 x^{2 * *}$ & 98.5 & $7.8 \mathrm{~b}$ & $7.0 \mathrm{~b}$ & 26.9 & 18.0 \\
\hline BRS Tupy & $\hat{y}=1.63+0.556 x-0.0106 x^{2 * *}$ & 97.5 & $8.9 b$ & $8.0 \mathrm{~b}$ & 26.0 & 17.0 \\
\hline BRS Xavante & $\hat{y}=1.72+0.231 x-0.0036 x^{2 * *}$ & 93.2 & $5.4 \mathrm{c}$ & $4.9 \mathrm{c}$ & 32.0 & 21.0 \\
\hline Average & - & - & & & 29.8 & 19.2 \\
\hline \multirow[t]{2}{*}{ CV (\%) } & & & 17.5 & & & \\
\hline & \multicolumn{6}{|c|}{ Fifth production cycle } \\
\hline Brazos & $\hat{y}=4.46+0.466 x-0.0078 x^{2 * *}$ & 90.0 & $11.4 \mathrm{a}$ & $10.3 \mathrm{a}$ & 30.0 & 18.0 \\
\hline Guarani & $\hat{y}=3.063+0.456 x-0.0088 x^{2 * *}$ & 92.8 & $8.9 b$ & $8.0 \mathrm{~b}$ & 26.0 & 17.0 \\
\hline BRS Tupy & $\hat{y}=1.806+0.4499 x-0.0071 x^{2 * *}$ & 97.7 & $8.9 \mathrm{c}$ & $8.0 \mathrm{a}$ & 32.0 & 21.0 \\
\hline BRS Xavante & $\hat{y}=1.14+0.249 x-0.0037 x^{2 *}$ & 89.5 & $5.3 \mathrm{c}$ & $4.8 \mathrm{c}$ & 34.0 & 22.0 \\
\hline Average & - & - & & & 30.5 & 19.8 \\
\hline CV $(\%)$ & \multicolumn{6}{|c|}{15.4} \\
\hline
\end{tabular}


The foliar $\mathrm{N}$ contents in the present study varied from 24.8 to $26.3 \mathrm{~g} \mathrm{~kg}^{-1}$ in plants fertilized with $20 \mathrm{~g}$ $\mathrm{K}_{2} \mathrm{O}$ in the two experimental years (Table 2). This range is within that of 22 to $30 \mathrm{~g} \mathrm{~kg}^{-1}$, which is considered normal for the optimal growth of blackberry according to the standards followed in Brazil (Freire, 2007; Manual..., 2016). The increase observed in $\mathrm{N}$ content in the present study occurred because the plants were able to absorb more $\mathrm{N}$ because they were well supplied with $\mathrm{K}$, which acts as a ion-charger in the transport of $\mathrm{NO}_{3}$ when $\mathrm{N}$ is not limiting (IPI, 2013).

The blackberry cultivars showed $\mathrm{P}$ content below normal for their optimal growth (Table 2). Therefore, $\mathrm{K}$ rates did not influence the content of this nutrient in the two evaluated years, considering the adequate range from 2.6 to $4.5 \mathrm{~g} \mathrm{~kg}^{-1}$ (Freire, 2007; Manual..., 2016). The low $P$ contents can be attributed both to the long productive period of the cultivars in the growing region, which increased the demand of the plants for $\mathrm{P}$, the third most exported nutrient by blackberry, as well as to the chemical and physical characteristics of the soil, which has low P contents and organic matter (Pereira et al., 2013b).

Foliar $\mathrm{Ca}$ and $\mathrm{Mg}$ contents varied during the two study years (Table 2). In the analysis performed during the fourth production cycle, the contents of both nutrients were not influenced by the $\mathrm{K}$ rates and were considered normal, ranging from 6.0 to $25 \mathrm{~g} \mathrm{~kg}^{-1}$

Table 2. Foliar nutrient contents of the Brazos, Guarani, BRS Tupy, and BRS Xavante (Rubus sp.) cultivars in response to potassium fertilization.

\begin{tabular}{|c|c|c|c|c|}
\hline Nutrient $^{(1)}$ & Equation $^{(2)}$ & $\mathrm{R}^{2}$ & Critical value ${ }^{(3)}$ (MEE) & $\mathrm{CV}(\%)$ \\
\hline & \multicolumn{4}{|c|}{ Fourth production cycle } \\
\hline $\mathrm{N}$ & $\hat{y}=20.3+0.456 x-0.0079 x^{2 * *}$ & 94.7 & 26.3 & 6.1 \\
\hline $\mathrm{K}$ & $\hat{y}=8.25+0.175 x^{* *}$ & 97.8 & 12.1 & 5.8 \\
\hline $\mathrm{P}$ & $\hat{y}=1.83^{\mathrm{ns}}$ & - & 1.83 & 9.4 \\
\hline $\mathrm{Ca}$ & $\hat{\mathrm{y}}=6.1^{\mathrm{ns}}$ & - & 6.1 & 10.8 \\
\hline $\mathrm{Mg}$ & $\hat{y}=3.6^{\mathrm{ns}}$ & - & 3.6 & 8.6 \\
\hline B & $\hat{y}=25.8^{\mathrm{ns}}$ & - & 25.8 & 8.9 \\
\hline $\mathrm{Fe}$ & $\hat{y}=146.9^{\text {ns }}$ & - & 146.9 & 11.1 \\
\hline $\mathrm{Zn}$ & $\hat{y}=19.6^{\mathrm{ns}}$ & - & 19.6 & 5.7 \\
\hline $\mathrm{Cu}$ & $\hat{\mathrm{y}}=4.97^{\mathrm{ns}}$ & - & 6.0 & 8.5 \\
\hline $\mathrm{Mn}$ & $\hat{y}=374.9^{\mathrm{ns}}$ & - & 374.9 & 15.2 \\
\hline \multicolumn{5}{|c|}{$\mathrm{K}$ availability in the soil $\left(\mathrm{mg} \mathrm{dm}^{-3}\right)^{(4)}$} \\
\hline $\mathrm{K}$ & $\hat{y}=25.24+2.874 x^{* *}$ & 97.2 & 82.7 & 19.8 \\
\hline \multicolumn{5}{|c|}{ Fifth production cycle } \\
\hline $\mathrm{N}$ & $\hat{y}=18.586+0.483 x-0.0086 x^{2 * *}$ & 95.6 & 24.8 & 5.2 \\
\hline $\mathrm{K}$ & $\hat{y}=7.66+0.216 x^{* *}$ & 96.9 & 12.0 & 5.4 \\
\hline $\mathrm{P}$ & $\hat{y}=1.63^{\mathrm{ns}}$ & - & 1.63 & 11.6 \\
\hline $\mathrm{Ca}$ & $\hat{y}=4.612-0.0242 x^{*}$ & 96.2 & 3.7 & 8.1 \\
\hline $\mathrm{Mg}$ & $\hat{y}=1.2$ & - & 1.2 & 8.9 \\
\hline B & $\hat{y}=25.767-0.156 x^{*}$ & 94.1 & 22.0 & 13.9 \\
\hline $\mathrm{Fe}$ & $\hat{y}=126.4^{\mathrm{ns}}$ & - & 126.4 & 10.6 \\
\hline $\mathrm{Zn}$ & $\hat{y}=20.3^{\mathrm{ns}}$ & - & 20.3 & 16.1 \\
\hline $\mathrm{Cu}$ & $\hat{y}=19.2$ & - & 19.2 & 18.8 \\
\hline $\mathrm{Mn}$ & $\hat{y}=747.5$ & - & 347.5 & 14.8 \\
\hline \multicolumn{5}{|c|}{$\mathrm{K}$ availability in the soil $\left(\mathrm{mg} \mathrm{dm}^{-3}\right)^{(4)}$} \\
\hline $\mathrm{K}$ & $\hat{\mathrm{y}}=15.245+2.994 \mathrm{x}^{* *}$ & 98.2 & 75.1 & 17.5 \\
\hline
\end{tabular}


and from 3.0 to $10 \mathrm{~g} \mathrm{~kg}^{-1}$, respectively (Freire, 2007; Manual..., 2016). In the fifth production cycle, a reduction was observed, with results lower than those of the previous cycle and below the ideal for plant growth and yield. These low contents may be related to the low availability of the nutrient in the soil and to the liming applied to improve the chemical attributes of the soil in the fifth production cycle. Although the relationship between $\mathrm{K}$ and $\mathrm{Ca}$ has been reported, under conditions of high $\mathrm{K}$ availability, there may be a decrease in $\mathrm{Ca}$ and $\mathrm{Mg}$ content likely due to the antagonistic effect of $\mathrm{K}$ (Castaño et al., 2008). In the present study, more representative decreases were verified from the fourth to the fifth production cycles, with a linear reduction of $\mathrm{Ca}$ in response to $\mathrm{K}$ rates only in the second year.

Foliar $\mathrm{Fe}, \mathrm{Zn}, \mathrm{Cu}$, and $\mathrm{Mn}$ contents were unaffected by $\mathrm{K}$ fertilization in the two evaluated years (Table 2 ) and were considered normal for optimal growth (Freire, 2007; Manual..., 2016). Mn contents were above normal and higher than $300 \mathrm{mg} \mathrm{kg}^{-1}$ during both years. Generally, in acid soils, Mn contents are more common above the adequate range than below it. This is due to the increase in the solubility and availability of this nutrient when soil pH is low (Hue \& Mai, 2002). Similar results have been reported for blackberry cultivars planted in soil with a $\mathrm{pH}$ of 5.9 (Pereira et al., 2015b). Although B content reduced in response to the $\mathrm{K}$ rates applied during the fifth production cycle (Table 2), it was considered insufficient in both experimental years, being $<30 \mathrm{mg} \mathrm{kg}^{-1}$ (Freire, 2007; Manual..., 2016). This difference in B content with increasing $\mathrm{K}$ fertilization may be attributed to the higher yield of the cultivars, since B is one of the most used micronutrients during flowering and fruit set (Dechen \& Nachtigall, 2006).

Cane density was influenced by $\mathrm{K}$ fertilization (Table 3). In the plants fertilized with $20 \mathrm{~g} \mathrm{~K}_{2} \mathrm{O}$, cane density increased from 59 to $69 \%$. However, the densities observed for the BRS Tupy and BRS Xavante cultivars were low, considering the ideal recommendation for the crop, varying from 5.7 to 13.1 canes per linear meter (Pagot et al., 2007). The low emission of new canes, at each production cycle, interferes with the yield performance of the cultivars, which may cause lower yields. To adjust cane density, as well as yield, the fertilization management must be balanced with the increase in $\mathrm{N}$ availability. In blackberry, $\mathrm{N}$ is the element used in the largest quantities and plays a major role in plant growth and development (Pereira et al., 2013a; Strik, 2008).

The increases in cane density were probably due to the structural and metabolic role of $\mathrm{K}$, which induces increased photosynthesis (Castaño et al., 2008) and, among other processes, favors $\mathrm{N}$ absorption (Table 2), which is important for cane growth.

The obtained results show that it is necessary to adjust $\mathrm{K}$ fertilization rates for the management of blackberry orchards growing in soils with a low $\mathrm{K}$ content, mainly because the current $\mathrm{K}$ fertilizer

Table 3. Number of new canes emitted by the Brazos, Guarani, BRS Tupy, and BRS Xavante blackberry (Rubus sp.) cultivars in response to potassium fertilization ${ }^{(1)}$.

\begin{tabular}{|c|c|c|c|c|}
\hline \multirow[t]{2}{*}{ Cultivar } & \multirow[t]{2}{*}{ Equation $^{(2)}$} & \multirow[t]{2}{*}{$\mathrm{R}^{2}$} & \multicolumn{2}{|c|}{ Canes (MME) } \\
\hline & & & Number per plant & \multirow[t]{2}{*}{ Density per meter } \\
\hline & & & on cycle & \\
\hline Brazos & $\hat{y}=0.914+0.137 x-0.0014 x^{2 *}$ & 98.2 & $3.1 \mathrm{~b}$ & $3.9 \mathrm{~b}$ \\
\hline Guarani & $\hat{y}=1.56+0.118 x^{*}$ & 95.2 & $4.0 \mathrm{a}$ & $5.0 \mathrm{a}$ \\
\hline BRS Tupy & $\hat{y}=2.1^{\mathrm{ns}}$ & - & $2.1 \mathrm{c}$ & $2.6 \mathrm{c}$ \\
\hline BRS Xavante & $\hat{y}=1.1+0.093 x^{* *}$ & 98.7 & $3.0 \mathrm{~b}$ & $3.7 \mathrm{~b}$ \\
\hline \multirow[t]{2}{*}{ CV (\%) } & \multicolumn{4}{|c|}{18.5} \\
\hline & \multicolumn{4}{|c|}{ Fifth production cycle } \\
\hline Brazos & $\hat{y}=0.55+0.419 x-0.0081 x^{2 * *}$ & 92.3 & $5.7 \mathrm{a}$ & 7.1a \\
\hline Guarani & $\hat{y}=1.5+0.15 x^{* *}$ & 93.7 & $4.5 b$ & $5.6 \mathrm{~b}$ \\
\hline BRS Tupy & $\hat{y}=0.703+0.175 x-0.0023 x^{2 * *}$ & 98.9 & $3.3 \mathrm{c}$ & $4.1 \mathrm{c}$ \\
\hline BRS Xavante & $\hat{\mathrm{y}}=0.6+0.133 \mathrm{x} * *$ & 97.4 & $3.3 \mathrm{c}$ & $4.1 \mathrm{c}$ \\
\hline CV $(\%)$ & \multicolumn{4}{|c|}{15.8} \\
\hline
\end{tabular}


recommendation does not promote an adequate plant growth and foliar $\mathrm{K}$ content.

\section{Conclusions}

1. The recommended potassium fertilization for the cultivation of blackberry (Rubus sp.) under Brazilian conditions is not sufficient to maintain an adequate nutrient foliar content, which should be evaluated to recommend the proper fertilization for the orchard, considering the higher plant demand to reach maximum fruit yield potential.

2. Potassium fertilization with $20 \mathrm{~g}$ per plant per year of $\mathrm{K}_{2} \mathrm{O}$ favors maximum economic efficiency yield, compatible with the yield performance of the studied cultivars.

\section{Acknowledgments}

To Coordenação de Aperfeiçoamento de Pessoal de Nível Superior (Capes), for scholarship (finance code 001); and to Conselho Nacional de Desenvolvimento Científico e Tecnológico (CNPq), for financial support (number 443371/2014-8).

\section{References}

ANTUNES, L.E.C.; PEREIRA, I. dos S.; PICOLOTTO, L.; VIGNOLO, G.K.; GONÇALVES, M.A. Produção de amoreirapreta no Brasil. Revista Brasileira de Fruticultura, v.36, p.100111, 2014. DOI: https://doi.org/10.1590/0100-2945-450/13.

ANTUNES, L.E.C.; RASEIRA, M. do C.B. (Ed.). Aspectos técnicos da cultura da amora-preta. Pelotas: Embrapa Clima Temperado, 2004. 54p. (Embrapa Clima Temperado. Documentos, 122).

CASTAÑO, C.A.; MORALES, C.S.; OBANDO, F.H. Evaluación de las deficiencias nutricionales en el cultivo de la mora (Rubus glaucus) en condiciones controladas para bosque montano bajo. Agronomía, v.16, p.75-88, 2008.

DECHEN, A.R.; NACHTIGALL, G.R. Micronutrientes. In: FERNANDES, M.S. (Ed.). Nutrição mineral de plantas. Viçosa: Sociedade Brasileira de Ciência do Solo, 2006. p.326-354.

FREIRE, C.J.S. Nutrição e adubação. In: ANTUNES, L.E.C.; RASEIRA, M. do C.B. (Ed.). Cultivo da amoreira-preta. Pelotas: Embrapa Clima Temperado, 2007. p.45-54. (Embrapa Clima Temperado. Sistemas de produção, 12).

HART, J.M.; STRIK, B.; REMPEL, H. Caneberries: nutrient management guide. Corvallis: Oregon State University, 2006. 8p.

HUE, N.V.; MAI, Y. Manganese toxicity in watermelon as affected by lime and compost amended to a Hawaiian acid Oxisol. HortScience, v.37, p.656-661, 2002. DOI: https://doi.org/10.21273/HORTSCI.37.4.656.

IPI. International Potash Institute. Potássio, o elemento da qualidade na produção agrícola. São Paulo, 2013. 36p. Available at: <https://www.ipipotash.org/udocs/419-kquality_booklet_ portuegese_web.pdf $>$. Accessed on: Dec. 172019.

IUSS WORKING GROUP WRB. World Reference Base for Soil Resources 2014: international soil classification system for naming soils and creating legends for soil maps: update 2015. Rome: FAO, 2015. (FAO. World Soil Resources Reports, 106).

MALAVOLTA, E.; VITTI, G.C.; OLIVEIRA, S.A. de. Avaliação do estado nutricional das plantas: princípios e aplicações. 2.ed. Piracicaba: Potafos, 1997. 319p.

MANUAL de calagem e adubação para os estados do Rio Grade Sul e Santa Catarina. 11.ed. Porto Alegre: Sociedade Brasileira de Ciência do Solo, Núcleo Regional Sul, Comissão de Química e Fertilidade do Solo - RS/SC, 2016. 376p.

OLIVEIRA, J. de; CRUZ, M. do C.M. da; MOREIRA, R.A.; FAGUNDES, M.C.P.; SENA, C.G. Productive performance of blackberry cultivars in altitude region. Ciência Rural, v.47, e20170021, 2017. DOI: https://doi.org/10.1590/0103$8478 \mathrm{cr} 20170021$.

PAGOT, E.; SCHNEIDER, E.P.; NACHTIGAL, J.C.; CAMARGO, D.A. Cultivo da amora-preta. Bento Gonçalves: Embrapa Uva e Vinho, 2007. 11p. (Embrapa Uva e Vinho. Circular técnica, 75).

PEREIRA, I. dos S.; NAVA, G.; PICOLOTTO, L.; VIGNOLO, G.K.; GONÇALVES, M.A.; ANTUNES, L.E.C. Exigência nutricional e adubação da amoreira-preta. Revista de Ciências Agrárias, v.58, p.96-104, 2015a. DOI: https://doi.org/10.4322/ rca.1755.

PEREIRA, I. dos S.; PICOLOTTO, L.; GONÇALVES, M.A.; VIGNOLO, G.K.; ANTUNES, L.E.C. Potassium fertilization affects floricane mineral nutrient content, growth, and yield of blackberry grown in Brazil. HortScience, v.50, p.1234-1240, 2015b. DOI: https://doi.org/10.21273/HORTSCI.50.8.1234.

PEREIRA, I. dos S.; PICOLOTTO, L.; MESSIAS, R. da S.; POTES, M. da L.; ANTUNES, L.E.C. Adubação nitrogenada e características agronômicas em amoreira-preta. Pesquisa Agropecuária Brasileira, v.48, p.373-380. 2013a. DOI: https://doi.org/10.1590/S0100-204X2013000400004.

PEREIRA, I. dos S.; SILVEIRA, C.A.P.; PICOLOTTO, L.; SCHNEIDER, F.C.; GONÇALVES, M.A.; VIGNILO, G.K.; ANTUNES, L.E.C. Constituição química e exportação de nutrientes da amoreira-preta. In: JORNADA DE PÓSGRADUAÇÃO E PESQUISA, 11.; MOSTRA DE INICIAÇÃO CIENTÍFICA, 11.; MOSTRA DE INICIAÇÃO CIENTÍFICA JÚNIOR, 9., 2013, Sant'Ana do Livramento. Anais. Sant'Ana do Livramento: Urcamp, 2013b. Congrega 2013.

SANTOS, H.G. dos; JACOMINE, P.K.T.; ANJOS, L.H.C. dos; OLIVEIRA, V.Á. de; LUMBRERAS, J.F.; COELHO, M.R.; ALMEIDA, J.A. de; CUNHA, T.J.F.; OLIVEIRA, J.B. de. Sistema brasileiro de classificação de solos. 3.ed. rev. ampl. Brasília: Embrapa, 2013. 353p. 
SILVA, F.C.da.(Ed.). Manual de análises químicas desolos, plantas e fertilizantes. 2.ed. Brasília: Embrapa InformaçãoTecnológica; Rio de Janeiro: Embrapa Solos, 2009. 627p.

STRIK, B.C. A review of nitrogen nutrition of Rubus. Acta Horticulturae, v.777, p.403-410, 2008. DOI: https://doi.org/10.17660/ActaHortic.2008.777.61.
STRIK, B.C.; BRYLA, D.R. Uptake and partitioning of nutrients in blackberry and raspberry and evaluating plant nutrient status for accurate assessment of fertilizer requirements. HortTechnology, v.25, p.452-459, 2014. DOI: https://doi.org/10.21273/HORTTECH.25.4.452. 